\title{
Mediating the German Ideology: Ordoliberal Framing in European Press Coverage of the Eurozone Crisis
}

\section{Ojala, Markus Mikael}

2016

Ojala , M M \& Harjuniemi , T J 2016 , ' Mediating the German Ideology: Ordoliberal Framing in European Press Coverage of the Eurozone Crisis ' , Journal of Contemporary European Studies , vol. 24 , no. 3 , pp. 414-430 . https://doi.org/10.1080/14782804.2015.1135109

http://hdl.handle.net/10138/233173

https://doi.org/10.1080/14782804.2015.1135109

acceptedVersion

Downloaded from Helda, University of Helsinki institutional repository.

This is an electronic reprint of the original article.

This reprint may differ from the original in pagination and typographic detail.

Please cite the original version. 
[This is the final accepted version of an article published in Journal of Contemporary European Studies 24(3): 414-430, available online: http://wwww.tandfonline.com/ 10.1080/14782804.2015.1135109]

Mediating the German Ideology: Ordoliberal Framing in European Press Coverage of the Eurozone Crisis

Markus Ojala (corresponding author)

University of Helsinki

Department of Social Research

P.O. Box 54

FI-00014 University of Helsinki

Finland

email: markus.ojala@helsinki.fi

Timo Harjuniemi (co-author)

University of Helsinki

Department of Social Research

P.O. Box 54

FI-00014 University of Helsinki

Finland

email: timo.harjuniemi@helsinki.fi

Acknowledgement: Research on this article was supported by the Helsingin Sanomat Foundation 
[This is the final accepted version of an article published in Journal of Contemporary European Studies 24(3): 414-430, available online: http://wwww.tandfonline.com/ $10.1080 / 14782804.2015 .1135109]$

\title{
Mediating the German Ideology: Ordoliberal Framing in European Press Coverage of the Eurozone Crisis
}

\author{
Markus Ojala \& Timo Harjuniemi \\ University of Helsinki
}

\begin{abstract}
The German government has played a leading role in the Eurozone crisis management, largely characterised by a commitment to fiscal austerity and supply-side structural reforms. The legitimation of these measures in the European policy arenas as well as in the public domain has partly rested on an ordoliberal economic policy framing, which has presented the Eurozone crisis as one of public indebtedness and loss of competitiveness. To study the public legitimation of the crisis management, we analyse the press coverage of the crisis in eight Eurozone member states, with a total of 7,986 newspaper articles included in the sample. Focusing on 'problem definitions' and 'treatment recommendations' as two key elements of issue framing, we find that an ordoliberal framing of the crisis prevails in all the studied countries, while a competing Keynesian policy frame is mostly undermined. Significant variation between the countries emerges, however, on the question of EU federalisation and on the framing of the sovereign bailout loans. We discuss the implications of these findings for the success of the German government to maintain the austerity orthodoxy across the Eurozone and crowd out economic policy alternatives.
\end{abstract}

KEY WORDS: Eurozone crisis, ordoliberalism, framing, newspapers

\section{Introduction}

References to Germany's leadership in the Eurozone have become widespread in popular and academic discourse in recent years (e.g. Hennessy 2013; Jessop 2014; Krampf 2014; Macmillan 2014; Meiers 2015). From the establishment of bilateral loan agreements and sovereign rescue funds to the strengthening of fiscal policy coordination among EMU countries, the German government has been identified as the key initiator of collective policy 
measures adopted in the wake of the Eurozone crisis. This apparent domination of Germany over the Eurozone has even prompted some to raise the question of whether the entire crisis has been managed 'to achieve optimal performance for the German economy' to the detriment of others (Orphanides 2014, 4). Whether or not this has been the case, economic policies across the currency area have by and large been characterised by fiscal conservativeness, internal devaluation, supply-side structural reforms and the implementation of new rules concerning public deficits and debt, all of them falling in line with approaches favoured by the German government.

Germany's leadership has certainly not remained unchallenged in the Eurozone crisis. The $\mathrm{ECB}$, for instance, has acted on several occasions against the will of its German board members, and the issue of Eurobonds has repeatedly resurfaced despite constant German opposition. German insistence on fiscal discipline and austerity in the middle of a prolonged recession has been met not only with widespread social protests in many Eurozone countries, but also with demands for Keynesian counter-cyclical measures by a number of prominent economists and European leaders (e.g. De Grauwe and Ji 2013; Krugman 2013; MNI 2013; Münchau 2014; RFI 2014; Wolf 2013). Many have seen France, representing a traditional coleader of European integration, as a balancing force to German domination in the EU, with France favouring at least partially different solutions to the Eurozone crisis from those preferred by the German government (e.g. Bogain 2014; Hall 2014; Van Esch 2014).

In the face of such political, social and intellectual opposition, the German government's leadership in the management of the Eurozone crisis has depended on its ability to convince the European policymakers and public of the need for austerity. Due to the largely intergovernmental nature of decision making in the Eurozone crisis (Fabbrini 2013; Heinrich and Kutter 2014), formal and informal meetings between government leaders and European officials are obvious contexts for such advocacy work. Yet, because national constituencies can put strong pressure on their governments to either conform to or oppose the policies preferred by Germany, the public domain also plays a significant role in the construction of policy acceptance. In its attempt to establish austerity as the leading principle in crisis management across the Eurozone, the German government has needed to seek popular support - or at least to minimise the opposition - beyond its own constituency.

In this article, we analyse the newspaper coverage of the Eurozone crisis in Germany, France, Italy, Spain, the Netherlands, Belgium, Greece and Finland to assess the extent to which the lines of reasoning preferred by the German government dominated the public debate across the Eurozone during the early stages of the crisis. To address the public legitimation of 
austerity policies, our analysis focuses on the similarities and differences in the economic policy framing of the Eurozone crisis in the studied countries. As has been noted in several recent studies, the German government has frequently drawn from the ordoliberal tradition of economic thought in order to garner support for its policy preferences in the crisis (e.g. Heinrich and Kutter 2014; Van Esch 2014; Young 2014). Accordingly, through a quantitative analysis of economic policy frames, we seek to determine the extent to which the German policy agenda, utilising an ordoliberal framing, has been successfully spread beyond the German debate, thus affecting the popular crisis narratives in the European press.

\section{Public Legitimation and Ordoliberal Framing}

Economic crises have often been taken advantage of by proponents of economic liberalism and transnational corporate interests to promote austerity, privatisations, cuts to social programs and services, and the deepening of 'market discipline' (Crouch 2011; Klein 2008; Mirowski 2013). Arguably, a transnational application of this 'shock doctrine' can now be witnessed in the introduction of similar 'treatments' across the Eurozone (e.g. Ryner 2014; Woestman 2012). At the same time, the burden that these measures and reforms place on workers, pensioners and taxpayers makes it necessary for decision makers to garner popular support for such 'sacrifices'. A key site for political legitimation is the news media, which connects European decision makers to European citizens and creates a space for the spreading of popular crisis narratives. Providing rationalisations for chosen policy measures, shaping public perceptions of the crisis and controlling the news agenda so as to prevent competing policy alternatives from gaining ground are key elements in public legitimation (Louw 2010; Tedesco 2011).

In terms of their efforts to legitimise austerity on a transnational scale, the Eurozone crisis has presented a unique opportunity to European leaders. During the crisis, the European news agenda has converged for extended periods, provided shared frames of reference and raised public awareness of the EU's impact on national economies, thus representing a potential turning point in the evolution of the European public sphere (Herkman and Harjuniemi 2015; Ojala 2013). At the same time, reflecting the intergovernmental management of the crisis, the European news agenda has been strongly oriented towards European institutions, including the Council and Euro Group meetings (Hubé, Salgado and Puustinen 2015), granting government leaders and finance ministers a privileged position in shaping the public definition of the crisis. Notably, in their comparative study on the news coverage of the Eurozone crisis, 
Hubé, Salgado and Puustinen (2015) found that Chancellor Merkel has been by far the most frequently quoted political leader in national newspapers across Europe ${ }^{1}$. As the consistently most visible decision maker in the European press, Merkel has effectively personified the politics of the crisis and emerged as the face of Germany's 'intellectual and moral leadership' in the Eurozone (Bulmer 2014, 1255). As the news tends to reflect the views of those journalists perceived to have the most power to influence the situation (Lawrence 2010, 269), Merkel's prevalence in the Eurozone crisis media coverage suggests that the German government has been at least partly successful in spreading its message and building public legitimation for austerity across the Eurozone.

In the study of political communication and news journalism, the influence of actors and points of view over the public agenda is often addressed through the concept of framing (e.g. McCombs and Ghanem 2001; Scheufele and Tewksbury 2007). In political discourse, frames are considered to be strategic resources employed by individuals or groups to promote a preferred policy or outcome (Pan and Kosicki 2001; Reese 2010, 20). Frames shape shared perceptions in society concerning public matters by selecting and emphasising certain aspects of social reality while excluding others in order to produce a certain interpretation of the issue (Borah 2011; Chong and Druckman 2007). Essentially, frames define the nature of a situation, provide a causal interpretation of the problem and offer a treatment recommendation in accordance (Entman 1993; Nelson and Willey 2001, 247). The issues and policies that form the decision-making agenda at any given time must be, to at least some extent, congruent with problem definitions and solutions that are recognised as legitimate and credible among the decision makers and the public at large. Accordingly, political elites need to package or frame policy proposals in order to convince each other, as well as the general public, that the proposed measures are plausible and generally accepted (see Campbell 1998, 380).

This is where, in our view, ordoliberalism comes into play. The ordoliberal tradition has an almost mythical position in the national narratives of the founding of the German 'social market economy' after World War II (Bonefeld 2012; Foucault 2008, 101-128; Hien 2013), and explicit references to its central tenets continue to occur in the public interventions of the German policy-making elite (e.g. Schäuble 2011; Stark 2008; Weidmann 2014). Developed by economists and jurists at the University of Freiburg in the 1930s, ordoliberalism laid the theoretical basis for a society and economy organised upon constitutional foundations (Vanberg 2004). The vision of rule-based 'order' (Ordnung) has also guided the development of economic policy ideas within the tradition, emphasising the need for a strong, yet constitutionally limited, state that uses its legislative and regulative powers to guarantee the 
operation of free and competitive markets (Bonefeld 2012; Hien 2013). With regard to macroeconomic policy, ordoliberalism prescribes supply-side measures, opposes Keynesian ideas of demand management and has a deep-seated mistrust of deficit spending (Dullien and Guérot 2012; Berghahn and Young 2013). Accordingly, German policies in the Eurozone crisis, in a number of recent accounts, have been at least partly attributed to the country's continuing fascination with the ordoliberal tradition (e.g. Berghan and Young 2013; Biebricher 2013; Dyson 2012; Hall 2014).

Our aim is not, however, to assess the extent to which Germany's policies can be explained or described in terms of the dictates of ordoliberalism. ${ }^{2}$ Instead, we focus on ordoliberalism's role as a strategic tool in the public legitimation of policy decisions (cf. Bulmer 2014; Young 2014). Quite apart from how they have followed ordoliberal orthodoxy, German governments have often found it useful, in their public rhetoric, to selectively invoke ordoliberalism with its positive association with the postwar Wirtschaftswunder in popular narratives. In political communication regarding the Eurozone crisis, the German government has been able to take advantage of popular European perceptions of Germany as a soundly managed economy to legitimise its leadership in the management of the crisis, and to promote that management with an ordoliberal framing of the crisis (cf. Heinrich and Kutter 2014; Van Esch 2014; Young 2014).

By ordoliberal framing we thus refer to the utilisation, in public discourse, of popularised ordoliberal ideas and rules of thumb to construct a simple, yet appealing, account of the crisis, which includes a definition of the problem (what is the principal cause of the crisis or the main problem that characterises the crisis) and a prescription of corresponding solutions (what are credible and realistic ways to politically and economically solve the defined problem). This is an account characterised by its concentration on debt, broken rules and loss of competitiveness (Blyth 2013, 141; Müller 2012). The roots of the crisis lie in the Eurozone's peripheral countries which are struggling with public and private sector deficits. The governments of these countries are guilty of running large fiscal deficits in violation of the EMU rules, overblown and over-indebted public sectors, overtly generous entitlements and policies that have failed to deter wage increases. Accordingly, reducing budget deficits via fiscal austerity, strengthening the fiscal rules of the EMU and engaging in supply-side structural reforms and wage cuts emerge as principal cures to the 'illness' (Meiers 2015, 2).

Given the centrality of the news media in shaping public interpretations of political issues and the continuing dominance of national media outlets in European public communication (Mancini and Mazzoni 2015), the German government's success in legitimising austerity rests, 
to a significant degree, on its capacity to control the public agenda and promote an ordoliberal framing of the crisis in each of the member states. At the same time, competing explanations must be downplayed and delegitimised as far as they point to radically contrasting policy solutions. Particularly damaging in this regard are interpretations that explain the crisis in terms of a lack of aggregate demand in the economy, emphasise the harmful effects of Germany's 'mercantilist' policies or point to the EMU's structural deficiencies as the principal cause of the crisis (e.g. Lucarelli 2012; Patomäki 2013; Varoufakis 2013). These counternarratives are often linked to policy proposals typically labelled in popular and academic discourse as 'Keynesian', and, consequently, the economic policy debate over the Eurozone crisis has often been characterised in terms of a clash between austerity-minded 'ordoliberals' and their 'Keynesian' opponents (e.g. Dullien and Guérot 2012; Van Esch 2014). Obviously, what in the public debate are called 'Keynesian policies' often have little to do with Keynesian economic theory per se (see, e.g., Davidson 2009). Yet the widespread use of the label suggests that, much like ordoliberalism, Keynesianism operates as a heuristic device for popularising certain interpretations of the crisis - and is therefore being used also as a strategic tool for legitimising economic policies. Correspondingly, in our analysis we use the notions of 'ordoliberal' and 'Keynesian' as labels for two competing diagnostic and prescriptive frameworks in the mainstream economic policy debates on the Eurozone crisis.

In the following sections, we seek to assess to what extent the German policy agenda and sense-making have permeated the public debate over the Eurozone crisis in the European press. Through a quantitative analysis of the Eurozone crisis press coverage in eight Eurozone countries, we observe the extent to which the press demonstrates significant national variation concerning the public interpretations of the crisis and assess whether a consistently dominant framing of the crisis emerges across the Eurozone. More specifically, by examining the news framing of the crisis, we seek to analyse to what extent the policy struggle between Germany's 'ordoliberalism' and a competing 'Keynesian' agenda is reflected in the European public debate.

\section{Material and method}

The analysis is based on the newspaper coverage of the Eurozone crisis in Germany, France, Italy, Spain, Holland, Belgium, Greece and Finland between February 2010 and July 2012. ${ }^{3}$ These early stages of the crisis were key with regard to issue framing, as many of the central management decisions, approaches and mechanisms were set during this period (see European 
Commission 2015). Moreover, during these stages, the European media attention was heavily tuned towards European decision makers and the dominant public interpretations of the crisis were established. If a consistent framing of the events could be secured then, elites could invoke it when necessary to legitimate subsequent policy measures, and competing political forces would have major difficulties in validating their points of view.

Within this period, newspaper articles were collected around 11 key news events related to the Eurozone crisis, including EU summits, major political developments and public interventions by central decision makers (see Table 1). Four national newspapers from each country were selected for the study, and the search words 'euro' and 'crisis' were used to locate the articles. Only relevant articles that explicitly dealt with the Eurozone crisis were selected for coding. Across the eight countries included in this analysis, a total of 7,986 articles were separately coded by a native speaker according to a predetermined coding framework which included 26 individual variables (for the complete coding book, see Picard 2015, 275-293).

\begin{tabular}{|l|l|}
\hline Collection period & Main event \\
\hline 4.-18.2.2010 & EU summit on crisis intervention (11.-12.2.) \\
\hline 25.4.-9.5.2010 & Eurozone agreement on 100bn euro intervention for Greece (2.5.) \\
\hline 9.-23.12.2010 & Changes to the EU Contract allowing emergency fund for Eurozone (16.12.) \\
\hline 25.7.-18.8.2011 & ECB requires Italy to increase austerity (5.8.) \\
\hline 28.9.-12.10.2011 & Greek general strike against austerity (5.10.) \\
\hline 19.10.-2.11.2011 & EU summit on new crisis measures (26.-27.10.) \\
\hline $5 .-19.11 .2011$ & Berlusconi resigns and Monti is appointed as Italy's PM (12.-13.11.) \\
\hline 20.-30.11.2011 & Commission issues Green Paper on European economic governance (23.11.) \\
\hline 16.5.-5.6.2012 & EU summit on boosting economic growth (23.5.) \\
\hline $18.6-5.7 .2012$ & Spain requests assistance (25.6.) and EU summit (28.-29.6.) \\
\hline 8.-22.7.2012 & Merkel demands Eurozone adherence to budget targets (15.7.) \\
\hline
\end{tabular}

Table 1. Summary of data collection periods

Drawing on earlier studies on political issue framing in the news (e.g. de Vreese 2005; Entman 1993; Lawrence 2010; Nelson and Willey 2001; Reese 2010), our quantitative analysis examines the operation of competing economic policy frames in the studied newspapers' coverage of the Eurozone crisis. As government leaders, finance ministers, EU commissioners and ECB officials meet to negotiate deals and announce policies, the press agenda is typically tuned towards informing readers about the decisions that policymakers are taking to address the Eurozone crisis. These measures are effectively presented as responses 
or solutions to a particular predicament, guiding public perceptions of the nature or root of the crisis as well as of proper ways to address it. The news thus contributes to particular framings of the Eurozone crisis with distinct problem definitions (PDs) and treatment recommendations (TRs). Accordingly, each article in the data was coded according to what it presented - if it did - as the principal cause of and policy response to the crisis.

The coding list concerning the presented roots and causes of the crisis consisted of 42 alternative PDs. These included various economic and social policy failures of individual governments, structural explanations pointing to the deficiencies of the EMU and institutional arguments concerning, for instance, the limits set in the Maastricht Treaty on the ECB to finance deficit spending in times of crisis. As regards TRs, each article was coded according to both the short-term policy response it promoted and the broader, more long-term reforms it presented as a way out of the crisis. A less detailed coding scheme was employed on TRs than the one used for PDs, with nine alternative short-term responses and seven longer-term reforms identified in the data. These ranged from such immediate policy measures as multilateral loans to countries with pressing liquidity problems to public stimulus and from such longer term solutions as competitiveness-enhancing structural reforms to the idea of individual nations exiting the Eurozone.

In the analysis, we identified those PDs and TRs that correspond with an 'ordoliberal' policy framing of the Eurozone crisis and assessed their relative salience against explanations and policy recommendations that are in tune with a popularised 'Keynesian' counter-narrative. The data also provided a number of representations of the crisis which did not clearly contribute either to an ordoliberal or a Keynesian frame or which could be used to support either one of the economic policy frames. These were listed accordingly as ambivalent PDs and TRs. In the following sections, we compare the results between the eight member states studied and discuss both the German influence and the impact of ordoliberal rhetoric on the public framing of the Eurozone crisis in the European press.

\section{Findings}

\section{Problem definitions}

As Table 2 illustrates, the issue of public debt, both across the Eurozone in general and in the countries with high fiscal deficits more specifically, is prevalent in the framing of the Eurozone crisis in all the studied countries. The concern over public finances, typically associated with an ordoliberal narrative of the crisis, dominates the debate over the roots of 
the crisis, particularly in the Finnish (46\% of all PDs), Belgian (33\%), German (32\%) and Greek (29\%) press. It is a salient issue in France (25\%), Italy (25\%) and the Netherlands (20\%) as well. In German newspapers, the lack of competitiveness in the most troubled countries complements fiscal profligacy in the ordoliberal framing, with an $18 \%$ share of all PDs. In the analysed 'southern' countries with high deficits during the period in question, lack of national competitiveness features as a relatively salient PD in the Greek (14\% of all PDs) and Spanish (13\%) press, but less so in Italy (4\%).

In contrast to the popularised ordoliberal PDs, Keynesian PDs are downplayed in the German debate. Only 8\% of German PDs point to the EMU and its structural deficiencies as a currency union or to the incompatibility of a common currency with the fiscal sovereignty of its users. Analyses of the Eurozone crisis as a consequence of the EMU's structural weaknesses are frequent particularly in France (26\% of all PDs), but Spanish (19\%), Italian (17\%), Dutch (15\%) and Finnish (15\%) newspapers also present these concerns with considerable frequency.

A significant amount of the European press coverage revolves around the role of banks, financial institutions and investors in and behind the Eurozone crisis. Such arguments appear mostly as ambivalent PDs, as they can be used to support both ordoliberal and Keynesian framings of the crisis. Emphasising the banking sector or market speculation against Eurozone governments may be used to place the crisis within a Keynesian reading of financialisation and its destabilising effects (Rossi 2013), but it can also support ordoliberal critiques, which point to the failure of regulators to guarantee well-functioning markets (cf. Weidmann 2014). Only in cases in which banks are criticised for lending to governments and enterprises on exceedingly easy terms and thus allowing the ballooning of public and private debt can a bankrelated PD be considered to contribute to an ordoliberal framing of the crisis.

The two Eurozone members subjected to the ESM loan programs stand out from the rest for different reasons. In Spain, a major part of the debate revolves around the failures of politics and the entire political class. Instead of being presented as a result of economic policy failures or structural dynamics, the crisis is framed as a general crisis of political culture. This apparently extra-economic focus makes a significant portion of the Spanish debate decisively ambivalent in terms of an ordoliberal or Keynesian framing of the crisis. For their part, Greek newspapers are strongly bent towards ordoliberal PDs, emphasising the problems of public debt and loss of competitiveness. However, these accounts are balanced to some degree by a positioning of the Eurozone crisis within the broader context of global capitalism. Accordingly, general macroeconomic developments in the globalised economy and financial 


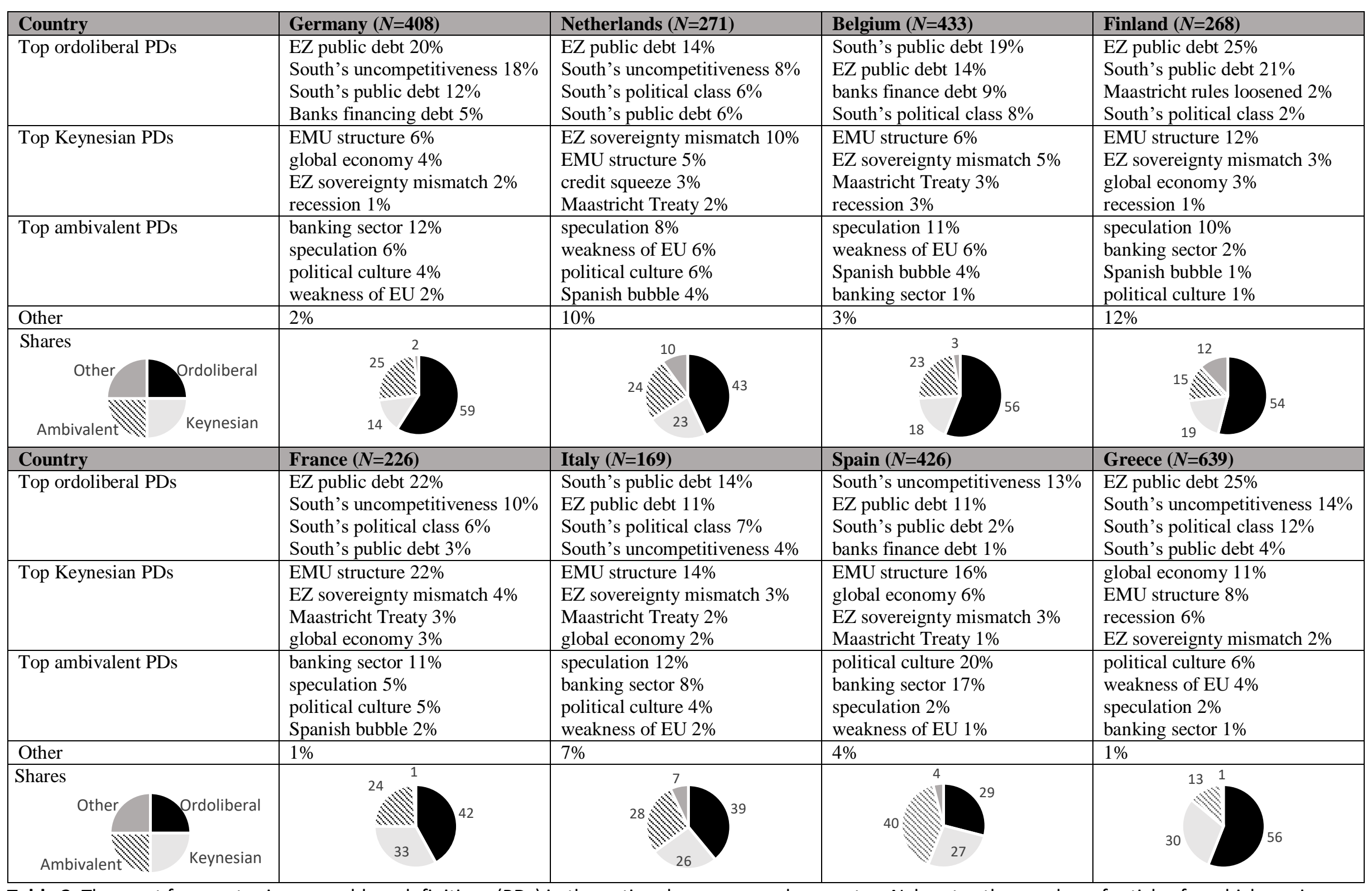

Table 2. The most frequent primary problem definitions (PDs) in the national newspapers by country. $N$ denotes the number of articles for which a primary PD was coded (only one PD per article was coded). 


\begin{tabular}{|c|c|c|c|c|}
\hline Country & Germany $(N=1256)$ & Netherlands $(N=813)$ & Belgium $(N=905)$ & Finland $(N=763)$ \\
\hline Ordoliberal TRs & $\begin{array}{l}\text { structural reforms } 24 \% \\
\text { conditioned loans } 21 \% \\
\text { fiscal austerity } 9 \%\end{array}$ & $\begin{array}{l}\text { structural reforms } 20 \% \\
\text { fiscal austerity } 9 \% \\
\text { conditioned loans } 2 \%\end{array}$ & $\begin{array}{l}\text { fiscal austerity } 18 \% \\
\text { structural reforms } 17 \% \\
\text { conditioned loans } 8 \%\end{array}$ & $\begin{array}{l}\text { conditioned loans } 18 \% \\
\text { structural reforms } 11 \% \\
\text { fiscal austerity } 8 \%\end{array}$ \\
\hline Keynesian TRs & $\begin{array}{l}\text { ECB loans and QE 8\% } \\
\text { debt haircut/amnesty } 4 \% \\
\text { eurozone breakup 4\% } \\
\text { fiscal stimulus } 1 \%\end{array}$ & $\begin{array}{l}\text { ECB loans and QE 9\% } \\
\text { debt haircut/amnesty } 4 \% \\
\text { eurozone breakup 2\% } \\
\text { fiscal stimulus }<1 \%\end{array}$ & $\begin{array}{l}\text { ECB loans and QE 9\% } \\
\text { debt haircut/amnesty 4\% } \\
\text { eurozone breakup 2\% } \\
\text { fiscal stimulus }<1 \%\end{array}$ & $\begin{array}{l}\text { ECB loans and QE 6\% } \\
\text { eurozone breakup 4\% } \\
\text { debt haircut/amnesty 3\% } \\
\text { fiscal stimulus 1\% }\end{array}$ \\
\hline Ambivalent TRs & $\begin{array}{l}\text { towards fiscal union } 8 \% \\
\text { growth policies 3\% } \\
\text { public bailouts 3\% }\end{array}$ & $\begin{array}{l}\text { towards fiscal union } 18 \% \\
\text { public bailouts } 17 \% \\
\text { growth policies } 3 \%\end{array}$ & $\begin{array}{l}\text { towards fiscal union } 17 \% \\
\text { public bailouts } 10 \% \\
\text { growth policies } 3 \%\end{array}$ & $\begin{array}{l}\text { public bailouts } 19 \% \\
\text { towards fiscal union } 10 \% \\
\text { growth policies } 3 \%\end{array}$ \\
\hline Other & $15 \%$ & $15 \%$ & $11 \%$ & $18 \%$ \\
\hline Shares & 17 & & 30 & $\$$ \\
\hline Country & France $(N=683)$ & Italy $(N=1124)$ & Spain $(N=1008)$ & Greece $(N=1778)$ \\
\hline Ordoliberal TRs & $\begin{array}{l}\text { structural reforms } 14 \% \\
\text { fiscal austerity } 13 \% \\
\text { conditioned loans } 4 \%\end{array}$ & $\begin{array}{l}\text { structural reforms } 17 \% \\
\text { conditioned loans } 11 \% \\
\text { fiscal austerity } 10 \%\end{array}$ & $\begin{array}{l}\text { structural reforms } 20 \% \\
\text { fiscal austerity } 13 \% \\
\text { conditioned loans } 7 \%\end{array}$ & $\begin{array}{l}\text { fiscal austerity } 18 \% \\
\text { structural reforms } 16 \% \\
\text { conditioned loans } 11 \%\end{array}$ \\
\hline Keynesian TRs & $\begin{array}{l}\text { ECB loans and QE } 10 \% \\
\text { eurozone breakup 5\% } \\
\text { debt haircut/amnesty 2\% } \\
\text { fiscal stimulus 1\% }\end{array}$ & $\begin{array}{l}\text { ECB loans and QE 8\% } \\
\text { eurozone breakup 8\% } \\
\text { debt haircut/amnesty 3\% } \\
\text { fiscal stimulus 1\% }\end{array}$ & $\begin{array}{l}\text { ECB loans and QE 11\% } \\
\text { eurozone breakup 5\% } \\
\text { debt haircut/amnesty 5\% } \\
\text { fiscal stimulus 3\% }\end{array}$ & $\begin{array}{l}\text { debt haircut/amnesty 9\% } \\
\text { ECB loans and QE 8\% } \\
\text { fiscal stimulus 7\% } \\
\text { eurozone breakup 5\% }\end{array}$ \\
\hline Ambivalent TRs & $\begin{array}{l}\text { towards fiscal union } 27 \% \\
\text { public bailouts } 17 \% \\
\text { growth policies } 3 \%\end{array}$ & $\begin{array}{l}\text { public bailouts } 11 \% \\
\text { towards fiscal union } 9 \% \\
\text { growth policies } 6 \%\end{array}$ & $\begin{array}{l}\text { towards fiscal union } 12 \% \\
\text { public bailouts } 6 \% \\
\text { growth policies } 5 \%\end{array}$ & $\begin{array}{l}\text { towards fiscal union } 14 \% \\
\text { growth policies } 4 \% \\
\text { public bailouts } 2 \%\end{array}$ \\
\hline Other & $4 \%$ & $15 \%$ & $13 \%$ & $6 \%$ \\
\hline $\begin{array}{l}\text { Shares } \\
\text { Other }\end{array}$ & 17 & 20 & 24 & ${ }_{28}^{21}$ \\
\hline
\end{tabular}

Table 3. Frequency of treatment recommendations (TRs) in the national newspapers by country. $N$ denotes the total number of TRs coded (up to two TRs could be coded for the same article). 
system, including the global financial crisis and the subsequent loss of demand in the global economy, are cited in the Greek debate as key drivers of the present predicament in the Eurozone.

Overall, the ordoliberal frame appears to have a strong presence when the causes of the Eurozone crisis are publicly defined in the European press. As Table 2 indicates, the share of ordoliberal PDs out of all presented PDs varies in most countries between $40 \%$ and $60 \%$. Only in Spain is the share considerably smaller, with only $29 \%$ of PDs clearly contributing to an ordoliberal framing of the crisis. The position of the ordoliberal frame is the strongest in German, Belgian and Finnish newspapers, where the share of Keynesian PDs remains smaller than 20\%. In France, Italy, Spain and the Netherlands, the difference in favour of an ordoliberal over Keynesian framing is markedly smaller.

\section{Treatment recommendations}

The tendency of the European press to emphasise 'ordoliberal' views over 'Keynesian' arguments is replicated when the focus turns to various policy solutions to the Eurozone crisis. As Table 3 illustrates, structural reforms and fiscal austerity together constitute $27-35 \%$ of all TRs presented in national newspapers outside Finland. 'Keynesian' solutions, in contrast, are largely marginalised, forming under $20 \%$ of TRs in most countries and gaining more substantial prominence only in Greek and Spanish newspapers. Moreover, the salience of measures that correspond with a 'Keynesian' diagnosis concerning the need to stimulate the economy is, by and large, restricted to the debate on the role of the ECB in expanding the supply of credit.

Overall, however, Table 3 presents a rather complex picture of the European public debate concerning policy solutions. Ordoliberal TRs enjoy only limited dominance in most countries, but instead of promoting 'Keynesian' calls for stimulus in direct opposition to austerity, the press coverage is to a significant degree characterised by TRs which are decidedly ambivalent in terms of their economic policy implication. Accordingly, one of the most prevalent TRs in the press concerns the idea of taking steps towards a fiscal union by granting more power to European institutions over national budgets. This is a particularly prominent feature in French newspapers (forming $27 \%$ of all TRs), seemingly corresponding with their emphasis on the EMU's dysfunctionalities when explaining the causes of the crisis and thereby possibly promoting a distinctly Keynesian framing of the crisis. However, the idea of increasing European institutions' capacities for budgetary control over member states also fits well with 
an 'ordoliberal' concern over the weakness of rule-based fiscal discipline across the Eurozone. This may explain the TR's popularity in Belgian (17\%) and Dutch (18\%) newspapers, with their noted concerns over public indebtedness.

The second ambivalent feature in the debate over policy solutions concerns decisions on inter-state financial assistance. The extension of loans and the establishment of common emergency funds for troubled members of the Eurozone has been a significant part of the debate in all creditor countries, ranging between $18 \%$ of all TRs in the Belgian press to a whopping 37\% in Finnish newspapers, although having a considerably smaller presence in the two recipient countries, Spain and Greece. Financial assistance for heavily indebted governments sits uneasily within an ordoliberal frame that emphasises fiscal discipline, and it can easily be seen to create a 'moral hazard' (cf. Dyson 2012). Only when the disciplinary aspect of loans is emphasised in the press can financial assistance be considered to contribute to a solution from an ordoliberal perspective. Accordingly, the high salience of the TR of 'conditioned loans' in the German and Finnish newspapers suggests that the elites in these countries have been partly successful in presenting financial assistance programs in 'ordoliberal' terms as a way to enhance fiscal discipline and competitiveness in the Eurozone. However, a significant part of the debate, particularly in France and the Netherlands, but also in Finland, has not emphasised the loans' conditionality but simply articulated the financial assistance programs as 'public bailouts' of troubled member state governments and their creditor banks. Even as the bailouts are typically legitimated by the need to prevent sovereign defaults and to stabilise the financial markets, without a clear association with austerity and fiscal discipline, they can hardly be regarded as an ordoliberal policy solution to the crisis and remain decidedly ambivalent with regard to their economic policy inclination.

As regards the capacity of the German government to shape the public framing of the Eurozone crisis, it is notable that the TRs which dominate the German public debate are not entirely replicated in other countries. The opinion leaders in the German press emphasise the need for national structural reforms and fiscal austerity and the imposition of such cures on the deficit countries through the conditionality of loans. At the same time, there appears to be little enthusiasm among the German elite to engage in institutional changes at the Eurozone level, which is consistent with their observed reluctance to acknowledge the institutional structures of the EMU as being at the heart of the problem. In comparison, while the rest of the countries tend to embrace fiscal austerity, enhancing competitiveness through structural reforms is less eagerly discussed outside Germany, and the idea of institutional reforms at the European level attracts more attention instead. Overall, then, outside Germany, the public 
debate tends to place less of the burden of adjustment on the shoulders of individual nations, and the idea that solutions need to be sought, coordinated and implemented at the European level is markedly more popular.

\section{Discussion: Eurozone press mediating the German frame?}

Previous studies have suggested that, in building domestic and transnational legitimacy to its policy approach in the Eurozone crisis, the German government has resorted to ordoliberalism as a tool for public framing (Van Esch 2014; Young 2014). Our findings indicate that its success has been the most evident among domestic constituencies, with the German press weaving the most consistent ordoliberal narrative of the Eurozone crisis. Accordingly, the German public debate has mostly concentrated on the high public debt levels in the Eurozone and has shed blame on the countries with large trade deficits for their fiscal and social policies that have led to the loss of competitiveness and public over-indebtedness. The cure to this malady includes cuts in public spending and structural reforms in order to reduce public debt and recover external competitiveness. Strictly conditioned loan programs are tools for reforming the profligate countries, according to these principles. Our results further suggest that, while being the most dominant in the German press, this line of reasoning is echoed to a large extent by the press of other member states as well.

The German government's apparent influence over the public framing of the Eurozone crisis can partly be attributed to Angela Merkel's ubiquity in the news coverage of the crisis (Hubé, Salgado and Puustinen 2015). Yet, while it guarantees that the German view on the crisis becomes widely circulated in the European press, it is certainly not the only reason for the noticeable prevalence of the ordoliberal frame. As the policy toolkit agreed on and implemented by European institutions has often reflected German views and even German interests (Orphanides 2014), the dominance of an ordoliberal framing in the public debate results at least as much from Germany's ability to set the political agenda of the Eurozone crisis as from Merkel's personal power to publicly legitimise those policies. Accordingly, many non-German members of the European elite, including national leaders and EU commissioners, have served, in effect, as public promoters of ordoliberal frames (see Rehn 2012; Van Esch 2014). It should also be noted that the German economic policy doctrine is deeply embedded in the very blueprint of the EMU defining, for instance, the European Commission's competences in fiscal policy surveillance and competition-enhancing reforms as well as the constitution and mandate of the ECB (Bulmer 2014; Maes 2004). The same 
applies to the Maastricht convergence criteria and the various fiscal pacts that form the nucleus of European economic governance (Biebricher 2013; Blyth 2013; Hall 2014). As much of the decision making in the Eurozone crisis and the institutional frameworks in which it is embedded are guided by ordoliberal principles, it is no wonder that the ordoliberal frame has a strong foothold in the European public debate.

There are two main fronts, however, on which the German government appears to lose its grip over the framing of the Eurozone crisis. On the one hand, a significant part of the debate outside Germany on the financial assistance programs has not emphasised their conditionality on austerity measures and structural reforms but has instead been characterised by nationalistic and Eurosceptic discourses and critiques of the financial sector. Hence, the ordoliberal frame has largely failed to provide legitimacy to this central policy measure in the Eurozone crisis. On the other hand, in countries in which the EMU's structural weaknesses feature prominently as part of the problem definition, there is less willingness than among the German elite to put the burden of adjustment on individual countries, and there is more emphasis on the need to strengthen European institutions.

Obviously, the idea of furthering federalisation may be defended as a way to overcome the disabling restrictions that the EMU imposes on individual governments in their efforts to manage aggregate demand in the economy. However, depending on one's view of preferable economic policies, it can also be presented as a means to increase fiscal discipline and control over profligate governments (cf. Hall 2014; Maes 2004). Therefore, the argument for the centralisation of power at the EU level can support both an ordoliberal and a Keynesian framing of the crisis. Low support in German newspapers for the idea of increasing the fiscal powers of the EU suggests, however, that the German elite tend to regard federalisation as a threatening step towards the loosening of the fiscal discipline which the EMU's current institutional structure imposes on its members as well as towards disturbing the economic dynamics between Eurozone economies which contribute to the success of the German exportled model (cf. Hall 2012). In contrast, in France and elsewhere, a stronger political union may be seen as a way to undermine German economic and political dominance but also as a means to fix the structural problems of the EMU which create threatening imbalances and lead to overall weaker growth in the Eurozone (cf. Patomäki 2013).

The political process during the Eurozone crisis has often been made sense of in terms of recurring rifts between 'creditors' and 'debtors', or in terms of increasing polarisation between 'northern' surplus countries and 'southern' deficit countries (Bogain 2014; Jessop 2014; Macmillan 2014). There are indications that such divisions are partly reproduced in the public 
sphere. Belgian, Finnish and Dutch newspapers tend to demonstrate greater conformity with the German agenda, while the dominance of the ordoliberal frame is weaker in French, Italian, Spanish and Greek newspapers. A counter-narrative of the EMU's structural deficiencies is popular particularly in France, suggesting that Keynesian economists and officials, who have traditionally enjoyed an influential position in the French political elite (Hall 1989, 20; Rosanvallon 1989), have been able to shape the national debate on the Eurozone crisis. However, even if a Keynesian frame may have significantly influenced the public problem definition outside the German-led camp, it seems to not have gained any foothold in the mobilisation of policy solutions in the early years of the Eurozone crisis. Aside from the calls for a fiscal union, the press coverage in France, Italy and Spain does not manifest any widespread mobilisation in public discourse of economic policy measures which would pointedly differ from those discussed in northern countries.

Greece is a partial exception to the rule. While austerity dominates the Greek debate as well, the relative plurality of views and topics indicates that there is less national consensus over the policy program and thus more room in the debate for alternative policies and frames. As the strong ascendance of the Syriza coalition in Greek politics after the outbreak of the crisis suggests, the left in Greece has been effective in formulating competing interpretations of the Eurozone crisis to those promoted by the German government, European institutions and Greece's conservative parties. While still remaining subordinated to the ordoliberal framing, these competing interpretations seem to have been able to infiltrate at least part of the national public debate in Greece even in the early years of the crisis.

\section{Conclusion}

As a starting point for the study we suggested, on the one hand, that the ability of the German government to largely dominate the European policymaking in the Eurozone crisis has been partly dependent on its ability to make its policy preferences credible and legitimate across the Eurozone and, on the other hand, that much of this public legitimation has taken place through the promotion of an ordoliberal framing of the crisis. Based on the quantitative and aggregate nature of the analysis presented in this paper, our findings indicating a significant penetration of ordoliberal framing across the Eurozone should be considered only as tentative propositions. A more refined analysis concentrating on internal divisions within each country, combined with a qualitative approach to examine more subtle differences in policy framing, 
would deliver a more complete picture of the various positions present in the European public debate.

With these reservations in mind, most of the views dominant in the German press seem to enjoy widespread popularity in the other studied Eurozone countries. The German agenda focusing on the imposition of new fiscal rules and austerity and the need for competitivenessenhancing structural reforms has been a prevalent feature of the public debate across the Eurozone. As much of this agenda follows popularised ordoliberal sense-making about the causes of the crisis, emphasising the problems of public debt, lack of fiscal discipline and loss of competitiveness, our findings suggest that the mainstream European press has actively contributed to the transnational mediation of 'the German ideology'. At the same time, our results complement observations made by others concerning the dominant role of the German government in policy formation during the Eurozone crisis. The German influence over the public framing of the crisis across the Eurozone complements the other two dimensions of its agenda-setting power in EU politics - over the political agenda of crisis management and over the very institutional structure of the EMU.

As the Eurozone has entered a prolonged period of weak growth and high unemployment, social, political and academic opposition has increased pressure for a change of course in European crisis management. In the face of these mounting challenges, the austerity orthodoxy championed by the German government has shown remarkable staying power and capacity to unite Eurozone leaders. Its success can partly be explained in terms of timing: an ordoliberal framing presenting austerity as a solution dominated the debate in the early stages of the Eurozone crisis and managed to shape the dominant public understanding of the crisis (cf. Salgado, Nienstedt and Schneider 2015, 123-124). Yet, it also indicates the absence of any fundamental differences between European elites when interpreting and addressing the crisis. Indeed, with the almost global success of the neoclassical school of economics (Mirowski 2013), there are reasons to assume that, even when oblivious to the theoretical and ideological foundations of much of their beliefs, the decision-making elites of the Eurozone countries tend to widely share similar understandings of the crisis and the available policy options (cf. Schulz-Forberg and Stråth 2010; Patomäki 2013).

However, despite its apparent pervasiveness, the ordoliberal dominance over the public definition of the Eurozone crisis is fragile. Social, political and economic consequences of the crisis continue to strain the capacity of German and European elites to legitimise austerity and provide the public with a credible narrative of the crisis that fits with these policies. When social, economic and political realities turn glaringly against the official framing, political 
alternatives may gain access even to the mainstream political debate, as the recent developments in Greece and Spain demonstrate. Indeed, signs of an open confrontation with the ordoliberal framing and of a notable politicisation of the Eurozone crisis were already visible in the Greek and Spanish debates during the early years of the crisis. With the prolonging and deepening crises of unemployment and welfare across the Eurozone, calls for more Keynesian alternatives may gather strength, producing both challenging frames and policy agendas against the ordoliberal consensus.

\section{References}

Berghahn, Volker and Brigitte Young. 2013. "Reflections on Werner Bonefeld's 'Freedom and the Stfong State: On German Ordoliberalism' and the Continuing Importance of the Ideas of Ordoliberalism to Understand Germany's (Contested) Role in Resolving the Eurozone Crisis." New Political Economy 18 (5): 768-778.

Biebricher, Thomas. 2013. "Europe and the Political Philosophy of Neoliberalism." Contemporary Political Theory 12 (4): 338-349.

Blyth, Mark. 2013. Austerity: The History of a Dangerous Idea. New York: Oxford University Press.

Bogain, Ariane. 2014. "Demons, Ants, Giants and Dwarves: The Construction of Germany's Handling of the Eurozone crisis in French Political Discourse." Journal of Contemporary European Studies 22 (1): 7-23.

Bonefeld, Werner. 2012. "Freedom and the Strong State. On German Ordoliberalism." New Political Economy 17 (5): 633-656.

Borah, Porismita. 2011. "Conceptual Issues in Framing Theory: A Systemic Examination of a Decade's Literature." Journal of Communication 61(2): 246-263.

Bulmer, Simon. 2014. "Germany and the Eurozone Crisis: Between Hegemony and Domestic Politics." West European Politics 37 (6): 1244-1263.

Campbell, John L. 1998: "Institutional Analysis and the Role of Ideas in Political Economy." Theory and Society 27: 377-409.

Chong, Dennis and James N. Druckman. 2007. "Framing Theory." Annual Review of Political Science 10: 103-26.

Crouch, Colin. 2011: The Strange Non-Death of Neoliberalism. Cambridge: Polity Press.

Davidson, Paul. 2009. The Keynes Solution. New York: Palgrave.

De Grauwe, Paul. 2010. "The Financial Crisis and the Future of the Eurozone". Bruges European Economic Policy (BEEP) Briefing 21/2010.

De Grauwe, Paul and Yuemei Ji. 2013. "Panic Driven Austerity in the Eurozone and its Implications." Vox, February 21. http://www.voxeu.org/article/panic-driven-austerity-Eurozone-and-its-implications 
De Vreese, Claes H. (2005). News Framing: Theory and Typology. Information Design Journal 13 (1): 51-62.

Dullien, Sebastian and Ulrike Guérot. 2012: The Long Shadow of Ordoliberalism: Germany's approach to the Eurozone crisis. European Council on Foreign Relations Policy Brief 49. http://www.ecfr.eu/article/commentary_the_long_shadow_of_ordoliberalism

Dyson, Kenneth. 2012. 'Maastricht Plus'. Managing the Logic of Inherent Imperfections. Journal of European Integration 34 (7): 791-808.

Entman, Robert. 1993. "Framing: Towards Clarification of a Fractured Paradigm." Journal of Communication 43 (4): 51-58.

European Commission. 2015. "Timeline: The Evolution of EU Economic Governance in Historical Context." European Commission. Accessed June 11. http://ec.europa.eu/economy_finance/economic_governance/timeline/index_en.htm

Fabbrini, Sergio. 2013. "Intergovernmentalism and its Limits: Assessing the European Union's Answer to the Eurozone crisis." Comparative Political Studies 46 (9): 1003-1029.

Foucault, Michel. 2008. The Birth of Biopolitics: Lectures at the Collège de France 1978-1979. New York: Picador.

Hall, Peter A. 1989: "Introduction." In The Political Power of Economic Ideas: Keynesianism across Nations, edited by Peter A. Hall, 3-26. Princeton: Princeton University Press.

Hall, Peter A. 2012. The Economics and Politics of the Euro Crisis. German Politics 21 (4): 355-371.

Hall, Peter A. 2014. "Varieties of Capitalism and the Eurozone crisis." West European Politics 37 (6): $1223-1243$.

Heinrich, Mathis and Amelie Kutter. 2013. "A Critical Juncture in EU Integration? The Eurozone Crisis and its Management 2010-2012." In Moments of Truth: The Politics of Financial Crises in Comparative Perspective, edited by Francisco Panizza and George Philip, 120-139. London: Routledge.

Hennessy, Alexandra. 2013. "Informal Governance and the Eurozone Crisis." Journal of Contemporary European Studies 21 (3): 430-447.

Herkman, Juha and Timo Harjuniemi. 2015. "Unity or Heterogeneity? The Promise of a European Public Sphere." In The Eurozone Crisis in the News. Journalistic Coverage of the Economic Crisis and European Institutions, edited by Robert G. Picard, 221-237. London: I.B. Tauris.

Hien, Josef. 2013. "The Ordoliberalism That Never Was." Contemporary Political Theory 12 (4): 349358.

Hubé, Nicolas, Susana Salgado and Liina Puustinen. 2015. "The Actors of the Crisis: Between Personalisation and Europeanization." In The Eurozone Crisis in the News. Journalistic Coverage of the Economic Crisis and European Institutions, edited by Robert G. Picard, 83-103. London: I.B. Tauris.

Jessop, Bob. 2014: "Variegated Capitalism, das Modell Deutschland, and the Eurozone Crisis. Journal of Contemporary European Studies 22 (3): 248-260. 
Klein, Naomi. 2008. The Shock Doctrine: The Rise of Disaster Capitalism. London: Penguin.

Krampf, Arie. 2014. "From the Maastricht Treaty to Post-crisis EMU: The ECB and Germany as Drivers of Change." Journal of Contemporary European Studies 22 (3): 303-317.

Krugman, Paul. 2013. "Those depressing Germans." New York Times, November 3. http://www.nytimes.com/2013/11/04/opinion/krugman-those-depressing-germans.html

Lawrence, Regina G. 2010. "Researching Political News Framing: Established Ground and New Horizons." In Doing News Framing Analysis. Empirical and Theoretical Perspective, edited by Paul D’Angelo and Jim A. Kuypers, 265-285. New York: Routledge.

Louw, Eric. 2010. The Media and Political Process. 2nd Edition. London: Sage.

Lucarelli, Bill. 2012. German neomercantilism and the European sovereign debt crisis, Journal of Post Keynesian Economics 34(2): 205-224.

Macmillan, Catherine. 2014. "The Return of the Reich? A Gothic Tale of Germany and the Eurozone Crisis.” Journal of Contemporary European Studies 22 (1): 24-38.

Maes, Ivo. 2004. "On the Origins of the Franco-German EMU Controversies." European Journal of Law and Economics 17 (21): 21-39.

Mancini, Paolo and Marco Mazzoni. 2015. "Countries Still Matter." In The Eurozone crisis in the News. Journalistic Coverage of the Economic Crisis and European Institutions, edited by Robert G. Picard, 177-195. London: I.B. Tauris.

McCombs, Maxwell and Salma I. Ghanem. 2001. "The Convergence of Agenda Setting and Framing." In Framing Public Life: Perspectives on Media and Our Understanding of the Social World, edited by Stephen D. Reese, Oscar H. Gandy Jr. and August E. Grant, 67-81. Mahwah: Lawrence Erlbaum Associates.

Meiers, Franz-Joseph. 2015. Germany's Role in the Euro Crisis. Heidelberg: Springer.

Mirowski, Philip. 2013. "Never Let A Serious Crisis Go to Waste." How neoliberalism survived the financial meltdown. London: Verso.

MNI. 2013. "EU's Rehn: More Domestic Demand in Germany Would Aid Eurozone." MNI, November 11. https://mninews.marketnews.com/content/eus-rehn-more-domestic-demand-germanywould-aid-Eurozone

Müller, Jan-Werner. 2012. "What Do Germans Think About When They Think About Europe?" London Review of Books 34 (3): 18-19.

Münchau, Wolfgang. 2014. "Merkel versus Renzi for the Future of the Eurozone." Financial Times, June 22. http://www.ft.com/intl/cms/s/0/342ef1a6-f7b9-11e3-b2cf-00144feabdc0.html

Nelson, Thomas E. and Elaine A. Willey. 2001. "Issue Frames that Strike a Value Balance: A Political Psychology Perspective." In Framing Public Life: Perspectives on Media and Our Understanding of the Social World, edited by Stephen D. Reese, Oscar H. Gandy Jr. and August E. Grant, 245-266. Mahwah: Lawrence Erlbaum Associates. 
Ojala, Markus. 2013. "Democratisation through Critique? The Eurozone Crisis and the Prospects of the European Public Sphere. IC - Revista Científica de Información y Comunicación 10: 75-98.

Orphanides, Athanasios. 2014. "The Euro Area Crisis: Politics over Economics." MIT Sloan School Working Paper 5091-6014. http://papers.ssrn.com/sol3/papers.cfm?abstract_id=2448197

Pan, Zhongdang and Gerald M. Kosicki. 2001. "Framing as a Strategic Action in Public Deliberation." In Framing Public Life: Perspectives on Media and Our Understanding of the Social World, edited by Stephen D. Reese, Oscar H. Gandy Jr. and August E. Grant, 35-65. Mahwah: Lawrence Erlbaum Associates.

Patomäki, Heikki. 2013. The Great Eurozone Disaster: From Crisis to Global New Deal. London: Zed Books.

Picard, Robert G, ed. 2015: The Eurozone crisis in the News. Journalistic Coverage of the Economic Crisis and European Institutions. London: I.B. Tauris.

Reese, Stephen D. 2010. "Finding Frames in A Web of Culture: The Case of the War on Terror." In Doing News Framing Analysis. Empirical and Theoretical Perspective, edited by Paul D'Angelo and Jim A. Kuypers, 17-42. New York: Routledge.

Rehn, Olli. 2012. "Europe Must Stay the Austerity Course." Financial Times, December 10. http://www.ft.com/intl/cms/s/0/35b77c12-42d6-11e2-a3d2-00144feabdc0.html

RISJ. 2013. "The Eurozone crisis, Media Coverage, and Perceptions of Europe within the EU." Reuters Institute for the Study of Journalism. https://reutersinstitute.politics.ox.ac.uk/research/research-focus-areas/business-and-financialreporting/the-euro-crisismedia-coverage-and-perceptions-of-europe-within-the-eu.html

RFI. 2014. "Hollande Calls for Flexibility in EU Budget Rules." RFI English, June 24, 2014. http://www.english.rfi.fr/economy/20140624-hollande-calls-flexibilities-eu-budget-rules

Rosanvallon, Pierre. 1989. "Keynesianism in France." In The political power of economic ideas: Keynesianism across nations, edited by Peter A. Hall, 171-193. Princeton: Princeton University Press.

Ryner, Magnus. 2014. "Eurozone Crisis". Academic Foresights 11 (May-August). http://www.academic-foresights.com/Eurozone_Crisis.html

Rossi, Sergio. 2013. "Financialization and Monetary Union in Europe: The Monetary-Structural Causes of the Euro-area Crisis". Cambridge Journal of Regions, Economy and Society, doi:10.1093/cjres/rst015

Salgado, Susanna, Heinz-Werner Nienstedt and Lennart Schneider. 2015. "Consensus Or Discussion? An Analysis of Plurality and Consonance in Coverage." In The Eurozone crisis in the News. Journalistic Coverage of the Economic Crisis and European Institutions, edited by Robert G. Picard, 103-125. London: I.B. Tauris.

Scheufele, Dietram A. and David Tewksbury. 2007. "Framing, Agenda Setting, and Priming: The Evolution of Three Media Effects Models.” Journal of Communication 57 (1): 9-20.

Schulz-Forberg, Hagen and Bo Stråth. 2010. The Political History of European integration: The hypocrisy of democracy-through-market. Abingdon: Routledge. 
Schäuble, Wolfgang. 2011. "From Financial to Debt Crisis. Financial Markets, Fiscal Policy and Public Debt in Europe's Monetary Union." Speech at the 4th Lindau Meeting in Economics, St. Gallen, August 27. http://www.bundesfinanzministerium.de/Content/EN/Reden/2011/2011-08-27$\underline{\text { nobelpreis-lindau.html }}$

Stark, Jürgen. 2008. "Monetary, Fiscal and Financial Stability in Europe." Speech at the 11th Euro Finance Week in Frankfurt, Frankfurt, November 18. http://www.ecb.europa.eu/press/key/date/2008/html/sp081118_1.en.html

Tedesco, John C. 2011. "Political Public Relations and Agenda Building." In Political Public Relations: Principles and Applications, edited by Jesper Strömbäck and Spiro Kiousis, 75-94. New York: Routledge.

Vanberg, Viktor J. 2004. "The Freiburg School. Walter Eucken and Ordoliberalism." .Freiburg Discussion papers on Consitutional Economics 4/11. Walter Eucken Institut, Albert-LudwigsUniversität Freiburg.

Van Esch, Femke. 2014. "Exploring the Keynesian-Ordoliberal Divide. Flexibility and Convergence in French and German Leaders' Economic Ideas During the Euro-Crisis." Journal of Contemporary European Studies 22 (3): 288-302.

Varoufakis, Yanis. 2013. The Global Minotaur. London: Zed Books.

Weidmann, Jens. 2014. "Of Dentists and Economists. The Importance of a Consistent Economic Policy Framework." Speech before the Juristische Studiengesellschaft, Karlsruhe, February 11. http://www.bis.org/review/r140217c.htm

Woestman, Lois. 2012. "Economic Shock Therapy in the Eurozone: The Greek case" Development 55 (3): 382-389.

Wolf, Martin. 2013. "Germany Is a Weight on the World." Financial Times, November 8. http://www.ft.com/cms/s/0/291a5ca6-42ec-11e3-8350-00144feabdc0.html

Young, Brigitte. 2014. "German Ordoliberalism as Agenda Setter for the Eurozone crisis: Myth Trumps Reality." Journal of Contemporary Studies 22 (3): 276-287.

\footnotetext{
${ }^{1}$ This finding is based on the same dataset as the one used in this study. See below for further details.

${ }^{2}$ Obviously, theoretical traditions can, at best, only partially explain the actual choices and policy preferences of decision makers (cf. Hall 1989, 10; Hennessy 2013). Actual policies result from an interaction of a complex set of factors, including not simply ideologies but also institutional limits, oppositional political forces, domestic pressures and the pragmatics of decision making. Accordingly, as much as it is influenced by an ordoliberal rationality, the German government's decision making in the Eurozone crisis can be explained, for instance,
} 
by the pragmatic considerations needed to reach compromises with other member states, by the need to appeal to domestic constituencies or to accommodate the interests of the banking sector and export industries or by the federal constitution defended and interpreted by the influential Constitutional Court.

${ }^{3}$ The dataset used in this analysis comprises the eight Eurozone member states which formed a part of an international research project 'The Eurozone crisis, Media Coverage and Perceptions within the EU', focusing on the portrayal of the Eurozone crisis in the national newspapers of 10 European countries (see RISJ 2013; Picard 2015). 